\title{
Proses Pembelajaran Tahfidz Alquran Terhadap Peserta Didik
}

\author{
Anwar Fuadi Jalil1, Alfurqan² \\ anwarfuadijalil@gmail.com¹ ${ }^{1}$, Alfurqan@fis.unp.ac.id ${ }^{2}$ \\ Universitas Negeri Padang ${ }^{1,2}$
}

\begin{tabular}{l}
\hline ARTICLE INFO \\
\hline Article history: \\
Received, 21 Oktober 2021 \\
Revised, 29 November \\
2021 \\
Accepted, 28 Februari \\
2022 \\
\hline
\end{tabular}

Keywords:

Pembelajaran, Tahfidz, Peserta didik

\section{Conflict of Interest:}

None

\section{Funding:}

None

\begin{abstract}
This study aims to: Knowing the process of learning tahfidz in improving the ability to memorize the Koran in class VI Khaira Ummah Islamic Elementary School, Padang City. To achieve the above objectives, a qualitative approach with the type of field research is used. Based on the results of observations, the author has determined that the informants who will be the main data sources in this study are 10 informants. The 10 informants were 1 principal, 1 student representative, 1 administrative person, represented by 2 educators, and 5 students. The results of this study indicate that 1) The tahfidz learning process in improving the ability to memorize the Koran in students at the Khaira Ummah Islamic Elementary School 2) Supporting and inhibiting factors for the tahfidz al-Quran learning process 3) Tahfidz learning solutions to overcome obstacles in memorizing the Koran. The benefits of this research are as follows: 1) Theoretical benefits are expected to be able to contribute to educational practitioners in providing scientific input related to the object of research and to increase the knowledge of Islamic religious education 2) Practical benefits, for institutions to improve teaching strategies in the learning process. memorizing the Koran and for schools as an evaluation and input for the school.
\end{abstract}

Corresponding Author: Anwar Fuadi Jalil, Department Islamic Education Faculty of Social Science Universitas Negeri Padang, Indonesia, Email: anwarfuadijalil@gmail.com, Phone No: $+6282170492342$

Copyright(C2022, Author(s)

\section{Pendahuluan}

Menghafal Alquran adalah sebuah upaya untuk memudahkan seseorang dalam memahami dan mengingat isi-isi Alquran dan untuk menjaga keaslianya serta menjadi sebuah amal shaleh bagi umat Islam. Adapun salah satu penjagaan Allah SWT terhadap Alquran adalah dengan memuliakan para penghafalnya. Menghafal Alquran dianjurkan untuk umat muslim, berbagai event lomba hafalan Alquran marak dilaksanakan di berbagai acara bahkan di beberapa stasiun televisi terkenal yang secara rutin mengadakan tayangan perlombaan tahfidz Alquran pada bulan suci 
ramadhan dimana pesertanya diikuti mulai dari tingkat anak-anak hingga dewasa (Akmal, 2021).

Alquran merupakan kitab suci yang mulia dan senantiasa terpelihara keaslian dan kemurniannya sampai hari kiamat. Alquran merupakan kalimat Allah yang tak akan pernah habis bila terus digali, yang membuat para sahabat terus haus untuk menimba ilmu Alquran. Para sahabat telah terukir dalam sejarah sebaik-baik generasi karena mereka tidak lepas dari hafalan Alquran sekaligus nilai-nilai yang terkandung di dalamnya. Antusias mereka begitu tinggi, rasa perhatian mereka begitu besar dan menggelora, semangat spiritual mereka mengalahkan nafsu mereka akan kenikmatan dunia. Mereka hidup dalam naungan Alquran berarti mereka selalu berinteraksi dengan Alquran baik secara tilawah (membaca), tadabbur (memahami), tahfizh (menghafalkan), tahfidz (mengamalkan), ta'lim (mengajarkan) dan tahkim (menjadikannya sebagai pedoman dan rujukan hukum) (Abu A'la al-Maududi, Mujahidin, \& Hafidhuddin, 2014) Alquran adalah pedoman hidup bagi umat Islam, sehingga mempelajari dan memahaminya merupakan kewajiban bagi umat Islam. Hal ini bisa dimulai sejak dini, yaitu masa anak-anak. Agar menumbuhkan rasa ingin tahu dalam mempelajari Alquran, dibutuhkan rasa cinta atau ketertarikan untuk mempelajarinya. Salah satu wujud cinta terhadap Alquran adalah dengan menghafalkan dan memahami maknanya serta menjaga hafalannya (Salamah, 2018).

Menurut Hashim (2015) Pendidikan tahfidz Alquran merupakan pendidikan paling awal dalam sejarah pendidikan islam. Menghafal juga merupakan metode yang digunakan oleh Nabi Muhammad SAW untuk mengajarkan Alquran kepada sahabatnya. Menghafal Alquran adalah sebuah upaya untuk mencegah agar Alquran tidak hilang dan menghindari segala upaya untuk memalsukan Alquran. Merujuk kepada kajian tahfidz Alquran dirasakan sangat perlu untuk dikembangkan. Banyak lembaga pendidikan Islam di indonesia saat ini yang mengembangkan progam tahfidz Alquran hal ini menunjukan antusiasme masyarakat muslim Indonesia yang tinggi untuk menghafal Alquran dan menjadikan anak-anak mereka sebagai penghafal Alquran. Tren ini juga sebagai tanda kemajuan pendidikan Islam. Meskipun sebetulnya menghafal Alquran bukanlah suatu hal yang baru bagi umat Islam, karena menghafal Alquran sudah berjalan sejak lama di pesantren-pesantren (Hidayah, 2016).

Menurut Mashud (2019) setiap muslim wajib mempelajari Alquran agar memiliki pengetahuan, pemahaman dan pengertian tentang aspek-aspek pendidikan, sosial, budaya, kisah dan suritaula dan sehingga dapat mengamalkannya dalam kehidupan sehari-hari. Pelajaran Alquran perlu diberikan kepada anak sejak usia balita, kanakkanak, remaja bahkan dewasa sekalipun karena Alquran adalah suatu kitab yang bersifat universal yang akan menjelaskan secara tersirat dan tersurat makna di dalamnya. Maka secara individu wajib mengimani Alquran sebagai kitab umat Islam. Oleh karena itu, mempelajari Alquran menjadi sebuah keharusan bagi semua pihak baik di lingkungan formal, informal, maupun non formal.

Salah satu metode tahfidz Alquran yaitu metode talaqqi merupakan metode yang diajarkan malaikat Jibril kepada Nabi Saw dalam menyampaikan Alquran, sebagaimana ketika wahyu pertama yaitu surat al-Alaq:1-5 diturunkan di Gua Hiro. Bahkan dalam beberapa riwayat diceritakan bahwa Nabi Saw selalu membacakan ayat Alquran kepada malaikat Jibril setiap bulan Ramadan. Metode talaqqi diajarkan oleh Rasulullah kepada para sahabatnya. Metode yang digunakan Nabi Saw merupakan salah satu metode yang banyak digunakan oleh para pengajar di berbagai macam 
tingkatan sekolah. Metode talaqqi memudahkan pengajar memilih cara yang tepat dalam menyampaikan ilmu, karena dengan bertemu langsung antara pengajar dan siswa, membuat pengajar lebih mudah mengenali kepribadian siswa, memudahkan pedidik mengawasi serta mengevaluasi hasil belajar siswa secara langsung (Rizalludin, 2019).

Sekolah Dasar Islam Terpadu (SDIT) diharapkan siswa memiliki kemampuan lebih dibandingkan dengan Sekolah Dasar (SD). Kemampuan yang diharapkan dari siswa SDIT antara lain siswa lebih mandiri, kreatif, memiliki akhlak yang mulia, bertaqwa serta terampil. Sistem yang digunakan oleh Sekolah Dasar Islam Terpadu (SDIT) berbeda dengan sistem yang digunakan oleh Sekolah Dasar atau sekolah reguler. Sistem pendidikan yang diterapkan di SDIT dinilai lebih bervariasi dari sistem pendidikan di SD umum (Marfu'ah dan Dewi, 2007).

Peneliti memilih salah satu SDIT di Kota Padang yaitu SD Islam Khaira Ummah. Berdasarkan dari hasil observasi awal yang dilakukan peneliti pada tanggal 08 juli 2021 pukul 11.30 wib, terkait dengan peningkatan kemampuan siswa dalam menghafal Alquran, peneliti juga melakukan wawancara kepada pihak terkait seperti guru tahfidz Pak Rino Ali, Adapun pertanyaan yang penulis ajukan kepada guru tahfidz adalah strategi apa yang bapak gunakan dalam meningkatkan kemampuan menghafal Alquran siswa? strategi yang bapak gunakan yaitu dengan menggunakan metode jama'dengan cara membaca Alquran bersama dengan siswa dan berapa. Penulis juga menanyakan bagaimana kondisi dan program hafalan di SD Khaira Ummah? kondisi siswa yang menghafal Alquran di SD Islam Khaira Ummah, pada saat ini masih ada permasalahan pada saat proses menghafal Alquran dan program yang dijalankan SD Islam Khaira Ummah siswa bisa hafal dua juz Alquran setelah tamat dari SD Islam Khaira Ummah.

\section{Tinjauan Pustaka}

Menurut Nasution (2017) strategi pembelajaran adalah keseluruhan pola umum kegiatan pendidik dan siswa dalam mewujudkan peristiwa pembelajaran yang efektif untuk mencapai tujuan, secara efektif dan efisien terbentuk oleh paduan antara urutan kegiatan, metode dan media pembelajaran yang digunakan, serta waktu yang digunakan pendidik dan siswa dalam kegiatan pembelajaran.

Dikutip dalam buku Bimbingan Praktis Menghafal Alquran menerangkan bahwa ada beberapa strategi menghafal yang baik, serta mempermudah mengingat ayat-ayat Alquran yang dihafalkan. Strategi tersebut antara lain adalah strategi pengulangan ganda, tidak beralih pada ayat berikutnya sebelum ayat yang dihafal benar-benar hafal dan memahami pengertian ayat-ayat yang dihafalkan (Al-Hafidz, 2003).

Di dalam strategi guru tahfidz untuk meningkatkan kemampuan menghafal Alquran siswa terdapat metode-metode yang dilakukan dalam proses menghafal Alquran. Menurut Al-Hafizh (2005) ada lima metode dalam menghafal Alquran yaitu metode wahdah adalah menghafal satu persatu ayat yang akan dihafal. Untuk mencapai hafalan awal, setiap aat harus dibaca sebanyak sepuluh kali atau lebih hingga proses ini mampu membentuk pola dalam bayangan, dan kemudian membentuk gerak reflek dari lisan. Setelah benar-benar hafal barulah dilanjutkan pada ayat berikutnya hingga mencapai satu halaman. Setelah ayat dalam satu halam hafal, tahap selanjutnya menghafal urutan ayat dalam satu halam tersebut, kemudian diulang-ulang sampai hafal. Metode kitabah (menulis) pada metode ini penghafal menulis dahulu ayat-ayat yang akan dihafalkan. 
Kemudian ayat tersebut dibaca hingga lancar dan benar bacaannya. Metode ini disamping membaca dengan lisan aspek visual menulis juga akan sangat membantu dalam mempercepat terbentuknya pola hafalan dalam bayangan. Metode simai (mendengar) pada metode ini penghafal mendengarkan terlebih dahulu ayat-ayat yang akan dihafalkan untuk kemudian diingat-ingat. Metode ini sangat cocok untuk anak tunanetra dan anak kecil yang belum mengenal baca tulis. Metode ini bisa dilakukan dengan mendengarkan bacaan dari guru dan rekaman bacaan Alquran (murattal Alquran). Metode gabungan merupakan gabungan antara metode pertama dengan metode kedua, yaitu wahda dan kitabah. Dalam metode ini penghafal berusaha untuk menghafalkan kemudian menulis apa yang telah dihafalkan dalam kertas. Metode jama' yang dimaksud dengan metode jama' adalah cara menghafal yang dilakukan dengan kolektif, atau bersama-sama yang dipimpin oleh seorang instruktur. Metode ini dapat menghilangkan kejenuhan dan dapat merangsang daya ingat terhadap ayat-ayat yang sedang dihafalkan.

Sedangan menurut Zuairini dan Abdul Ghofir (2004) ada empat metode dalam menghafal Alquran. Pertama, merefleksi yakni memperhatikan bahan yang sedang dipelajari, baik dari segi tulisan, dan tanda bacaannya. Kedua, mengulang yaitu membaca dan mengikuti berulang-ulang apa yang diucapkan guru. Ketiga, meresitasi yaitu mengulang secara individual untuk menunjukkan perolehan hasil belajar tentang apa yang telah dipelajari. Keempat, retensi yakni ingatan yang telah dimiliki mengenai apa yang telah dipelajari yang bersifat permanen.

Menurut Hidayat (2018) Guru tahfidz yaitu pelaksana program tahfidz dan hal-hal yang sifatnya keagamaan. Guru tahfidz di sini berperan sebagai figur yang memberikan teladan melalui pendekatan keagamaan dan pendalaman materi tentang konsep diri yang positif pada peserta didik penghafal Alquran saat melakukan setoran hafalan atau saat peserta didik berada di kelas tahfidz. Upaya untuk meningkatkan konsep diri peserta didik penghafal Alquran salah satunya yaitu dengan memberikan nasihat. Nasihat di sini yaitu guru tahfidz memanggil salah satu peserta didik mengarahkan teman-temannya jika sudah waktunya masuk pembelajaran tahfidz untuk segera masuk ke kelas dan tidak bermain di luar kelas. Dari nasehat-nasehat yang diberikan kepada peserta didik dapat mempengaruhi visi diri, yaitu bagaimana harus berperilaku serta peran diri peserta didik dapat memposisikan diri sebagaimana mestinya. Sedangkan menurut Darimi (2015) Pendidik dalam prespektif pendidikan Islam ialah orang yang bertanggung jawab terhadap upaya perkembangan jasmani dan rohani siswa agar mencapai tingkat kedewasaan sehingga dia mampu menunaikan tugastugas kemanusiaannya sesuai dengan nilai-nilai ajaran agama Islam.

\section{Peran guru tahfidz}

Menurut UU No. 20 Tahun 2003 dan UU No. 14 Tahun 2005, peran guru adalah sebagai pendidik, pengajar, pembimbing, pengarah, pelatih, penilai dan pengevaluasi dari peserta didik. Adapun peran guru, antara lain Guru sebagai pendidik merupakan tokoh utama sebagai seorang pendidik. Menjadi panutan atau acuan bagi setiap siswa, menjadi teladan yang baik, berwibawa, bertanggung jawab, kedisiplinan, dan mandiri. Itu semua menjadi kualitas yang harus dimiliki oleh guru. Dalam menjalankan tugasnya, sorang guru harus bertanggung jawab dalam proses pembelajaran yang 
dilakukannya serta berani mengambil keputusan dengan mandiri agar menjadikannya guru yang memiliki kompetensi yang baik.

Guru sebagai pengajar yaitu dalam perkembangan siswanya, seorang guru harus bisa membantu siswanya yang dalam tahap berkembang untuk mempelajari sesuatu yang belum diketahuinya, harus memahami materi yang sedang diajarkannya agar terbentuk guru yang memiliki standar kompetensi yang baik. Sebagai pengajar, seorang guru harus bisa mengikuti perkembangan zaman yang yang ada, harus bisa mengikuti perkembangan teknologi yang semakin canggih sehingga apa yang disampaikan kepada sisawa menjadikan hal-hal yang harus diperbarui. Semakin berkembangnya zaman dan teknologi yang semakin canggih, menjadikan peran guru semakin berubah, seperti peran guru bukan hanya sebagai pengajar yang bertugas untu menyampaikan materi yang diajarkan, akan tetapi seorang guru juga sebagai fasilitator yang tugasnya memberikan kemudahan bagi para siswanya dalam belajar.

Guru sebagai pembimbing yaitu dalam menjalankan perannya sebagai pembimbing, seorang guru harus bisa mencari jalan keluar dan memutuskan tujuannya secara jelas dan akurat sesuai dengan kebutuhan siswanya. Dalam menjalankan semua kegiatan yang dilakukan oleh guru harus bekerjasama dengan siswanya agar tercapainya tujuan yang hendak dicapai bersama-sama, karena guru memiliki hak dan tanggung jawab dalam setiap rencana yang dilaksanakannya.

Menjadi guru tidaklah mudah, guru dituntut untuk dapat mengarahkan siswanya dalam mengembangkan potensi diri yang dimiliki siswa agar dapat membangun karakter yang baik bagi diri siswa itu sendiri dalam kehidupan di masyarakat. Tidak hanya itu, seorang guru juga harus bisa megarahkan dan mengajarkan siswanya dalam memecahkan berbagai permasalahan yang telah dihadapi, memberikan motivasi kepada siswa dalam mengambil keputusan dan membantu menemukan jati diri dari siswanya.

Setiap siswa memiliki kemampuan yang berbeda-beda, sehingga membutuhkan latihan dalam keterampilan, baik itu intelektual maupun motorik, sehingga menjadikan seorang guru bentindak sebgai pelatih. Untuk itu, guru harus memiliki pengetahuan yang tinggi, meskipun tidak mencakup semua pengetahuan, setidaknya guru tau apa yang harus dilakukannya terhadap siswanya.

Setiap ada pembelajaran pasti ada yang namanya penilaian. Penilaian dilakukan oleh guru yang berkaitan. Dengan adanya penilaian, guru dapat menetapkan kualitas hasil belajar yang dicapai siswanya, atau proses untuk menentukan tingkat penjacapaian tujuan pembelajaran siswanya. Sebagai suatu proses, penilaian dilaksanakan dengan prinsipprinsip dan dengan teknik yang sesuai, baik tes atau nontes. Teknik apapun yang dipilih, penilaian harus dilakukan dengan prosedur yang jelas meliputi tiga tahap, yaitu persipan, pelaksanaan dan tindak lanjut.

Menurut Sanusi (2013) seorang guru tahfidz dituntut tidak hanya mengajarkan ilmu pendidikan tahfidz semata dalam proses pembelajaran, tetapi juga melakukan usahausaha lainnya yang dapat membantu tercapainya tujuan pendidikan agama Islam. Usaha-usaha tersebut antara lain diwujudkan melalui upaya guru tahfidz dalam menumbuhkan suasana religius di sekolah. Adapun yang dimaksud dengan suasana religius adalah terciptanya situasi keagamaan di kalangan pendidik dan anak didiknya yang tercermin dalam usaha memahami ajaran-ajaran agama, budi luhur dari peserta 
Anwar Fuadi Jalil dan Alfurqan : Proses Pembelajaran Tahfidz Alquran ....

didik, hidup sederhana dan hemat, mencintai kebersihan, dan segera menyadari dan memperbaiki kesalahan.

\section{Menghafal Alquran}

Secara harfiah menghafal berasal dari bahasa arab (hafidza, yahfadzu, hifdzan) yang artinya memelihara, menjaga, dan menghafalkan. Tahfidz (hafalan) secara etimologi adalah lawan dari lupa, yaitu selalu ingat dan sedikit lupa. Dalam Kamus Besar Bahasa Indonesia disebutkan bahwa kata hafal berarti "telah masuk dalam ingatan dan dapat mengucapkan kembali tanpa melihat buku (Latifah, 2016). Sedangkan menurut Mahmud (2010) menghafal merupakan reaksi elektrokimia rumit yang diaktifkan melalui beragam saluran indrawi dan disimpan dalam jaringan saraf diseluruh bagian otak. Menurut Qoyyum (2009: 12), menghafal adalah menyampaikan ucapan di luar kepala tanpa melihat teks, mengokohkan dan menguatkannya di dalam dada, sehingga mampu menghadirkan ilmu itu kapanpun dikehendaki.

Secara etimologi Alquran berasal dari bahasa Arab dalam bentuk kata abstrak mashdar dari kata (qara'a, yaqrau, qur'anan) yang berarti bacaan. Menurut Akmal (2021) Alquran adalah wahyu Allah yang diturunkan kepada nabi Muhammad SAW melalui malaikat jibril sebagai pedoman bagi umat manusia yang apabila membacanya merupakan ibadah sekaligus sebagai mukjizat dari Allah dan selalu terjaga kemurnian dan kesuciannya sampai akhir zaman (Akmal, 2021). Menurut Fachrudin (2017) menghafal Alquran adalah proses untuk memelihara, menjaga dan melestarikan kemurnian Alquran agar tidak terjadi perubahan dan pemalsuan serta dapat menjaga dari kelupaan baik secara keseluruhan maupun sebagiannya. Jadi menghafal Alquran adalah aktivitas menjaga, memilihara, dan menghafal ayat-ayat Alquran semuanya. Semua yang dihafalkan tersebut mencakup apa yang dilihat, huruf demi huruf, dibaca, letak, waqafnya, dan sebagainya. Semuanya direkam sesuai dengan tingkat kekuatan dan kemampuan daya ingat. Cara menghafal Alquran menurut Gade (2014) untuk membantu mempermudah membentuk kesan dalam ingatan terhadap ayat-ayat yang dihafal, maka diperlukan strategi yang baik yaitu strategi pengulangan ganda, tidak pernah beralih pada ayat berikutnya sebelum ayat yang sedang dihafal benar-benar terhafal, Menghafal urutan-urutan yang dihafalnya dalam satu kesatuan jumlah setelah benar-benar hafal ayatnya, menggunakan satu jenis mushaf saja, memahami ayat-ayat yang dihaafalnya, memperhatikan ayat-ayat yang serupa, dan disetorkan pada seseorang yang mampu menghafal Alquran.

Menurut Fanani (2016) ada dua faktor yang menjadi penyebab lemahnya minat siswa dalam mengahafal yaitu faktor internal dan eksternal. Faktor internal yaitu malas melakukan simaan, bersikap sombong, tidak mengulang hafalan secara rutin, terlalu berambisi menambah banyak hafalan baru, tidak sungguh-sungguh, tidak menguasai makhorijul huruf dan tajwid, malas, sering lupa. Faktor eksternal yaitu berlebihan dalam memandang dunia, tidak menjauhi perbuatan dosa, tidak melaksanakan shalat hajat dan tidak menghindari dan menjauhi maksiat. Sedangkan menurut Siswanto (2018) faktor yang menjadi penyebab lemahnya minat siswa dalam mengahafal Alquran secara benar dan fasih, yaitu disebabkan oleh beberapa hal antara lain kurang adanya dukungan dari orang tua, teman dan lingkungan. Siswa tidak pernah diajak untuk menghafal surat-surat dengan benar dan fasih. Hafalan siswa juga tidak dikoreksi secara individu dengan memperhatikan makhroj dan tajwid yang benar, kurang tepatnya metode yang diguanakan dalam proses pembelajaran, tidak sesuai dengan kondisi siswa pada dasarnya masih suka bermain-main. Penggunaan 
metode yang monoton serta tidak menarik yang akhirnya membuat siswa merasa bosan dan sulit dalam menghafal.

\section{Metode}

Jenis penelitian yang akan peneliti gunakan ialah penelitian lapangan (field research) yang bersifat kualitatif. Penulis menggunakan metode penelitian kualitatif pendapat ini sebagaimana dinyatakan Semiawan (2010) metode kualitatif adalah suatu pendekatan atau penelusuran untuk mengekplorasi dan memahami suatu gejala sentral. Anggito \& Setiawan (2018) menyatakan bahwa penelitian kualitatif adalah penelitian yang menggunakan latar alamiah dengan maksud menafsirkan fenomena yang terjadi dan dilakukan dengan jalan melibatkan berbagai metode yang ada. Sedangkan menurut Sugiyono (2008) metode penelitian kualitatif adalah metode penelitian yang berlandaskan pada filsafat postposivisme, digunakan untuk meneliti pada kondisi objek alamiah, dimana peneliti adalah adalah sebagai intrumen kunci, teknik pengumpulan data dilakukan secara triangulasi (gabungan), analisis data bersifat induktif/kualitatif dan hasil penelitian kualitatif lebih menekankan makna dari pada generalisasi.

Peneliti memilih menggunakan jenis penelitian ini agar data-data yang peneliti dapatkan dilapangan merupakan data yang aktual atau data yang benar-benar terjadi pada keadaan sekarang yang diobsevasi secara langsung untuk dipertanggung jawabkan dan dapat dipercaya. Untuk menentukan jumlah informan yang akan dilibatkan dalam penelitian ini, maka penulis melakukan observasi awal ke lokasi penelitian. Berdasarkan hasil observasi tersebut maka penulis telah menetapkan informan yang akan menjadi sumber data utama dalam penelitian ini adalah 18 orang. Adapun 10 orang informan tersebut adalah 1 orang kepala sekolah, 1 orang wakil kesiswaan, 1 orang tenaga usaha, diwakili 2 orang pendidik dan 5 orang peserta didik. penulis menggunakan teknik Purposive Sampling pendapat ini sebagaimana di ungkapan oleh Sugiyono (2008) purposive sampling adalah teknik penentuan sampel berdasarkan pada pertimbangan tertentu. Menurut Sugiyono (2008) analisis data memiliki tiga tahapan kegiatan yaitu: reduksi data, penyajian data dan penarikan kesimpulan. Sebagaimana yang telah penulis jelaskan sebelumnya, sumber data utama didapatkan melalui wawancara dengan informan dalam bentuk catatan tulisan, pembangbilan foto atau video dan selanjutnya analisis dokumen dari seluruh dokumentasi yang terdapat ditempat penelitian baik secara tertulis dan dokumentasi.

Langkah selanjutnya dalam analisis reduksi data yaitu merangkum, memilih datadata yang pokok, memfokuskan pada data-data yang penting, dicari tema dan polanya (Sugiyono, 2008). Proses ini berlangsung secara terus menerus selama penelitian berlangsung, bahkan sebelum data benar-benar terkumpul sebagaimana terlihat dari kerangka konseptual penelitian, permasalahan studi dan pengumpulan data yang dipilih peneliti. Sedangkan penyajian data merupakan sekumpulan data yang telah tersusun secara rapi sehingga memberi kemungkinan akan adanya penarikan kesimpulan dan pengambilan tindakan. Bentuk penyajian data kualitatif berupa teks yang sifat naratif (Sugiyono, 2008). Dengan adanya suatu penyajian data tersebut, memudahkan peneliti untuk melihat apa yang terjadi dan tindakan apa yang harus peneliti lakukan berdasarkan pengertian yang telah dipahami. Langkah ketiga yaitu 
penarikan kesimpulan, peneliti selalu melakukan penarikan kesimpulan selama peneliti berada di lokasi penelitian. Penarikan kesimpulan dilakukan dengan cara mengumpulkan data yang telah ada dan mencari data yang sering timbul, kemudian disimpulkan. Kesimpulan, harus didukung oleh bukti-bukti yang valid dan konsisten saat peneliti berada dilapangan untuk mengumpulkan data, agar kesimpulan sesuai dengan fakta yang terjadi lapangan (Sugiyono, 2008). Dari penjelasan yang telah penulis paparkan di atas, maka dapat dipahami bahwa setelah mengumpulkan data kegiatan analisis data kualitatif memiliki keterkaitan dengan aktivitas reduksi data, penyajian data dan penarikan kesimpulan hasil penelitian.

\section{Hasil dan Pembahasan}

\section{Proses Pembelajaran Tahfidz Alquran Terhadap Peserta Didik}

Sebagaimana telah penulis jelaskan sebelumnya bahwa, hasil penelitian ini bersumber dari dua sumber yaitu melalui wawancara dengan informan dan analisis dokumen dari seluruh dokumentasi yang terdapat ditempat penelitian baik secara tertulis dan dokumentasi. Data yang diambil melalui wawancara kepada 10 orang informan tersebut adalah 1 orang kepala sekolah, 1 orang wakil kesiswaan, 1 orang tata usaha, diwakili 2 orang pendidik dan 5 orang peserta didik. Agar hasil penelitian tahap pertama mudah dipahami, seluruh hasil wawancara dengan informan telah penulis transkrip ke dalam bahasa yang lebih sederhana dan dilaporkan dalam bentuk percakapan. Transkrip tersebut kemudian direduksi kembali sehingga hasil wawancara yang ditampilkan betul-betul sesuai dengan tujuan penelitian. Seluruh wawancara yang telah direduksi tersebut selanjutnya penulis sajikan data tersebut guna mempermudah memahami hasil dari penelitian ini. Berikut peneliti sajikan kutipan hasil wawancara dengan pak Sahardi, S.IQ, S.Pd. I dan pak Rino Ali, S.Pd.I yang menjabat sebagai guru tahfidz di Sekolah Dasar Islam Khaira Ummah Kota Padang. Proses wawancara ini dilakukan pada hari Senin 23 agutus dan Senin 30 Agustus 2021 di ruangan kelas Sekolah Dasar Khaira Ummah Padang.

Tabel 1. Petikan Wawancara Tentang Proses Pembelajaran Tahfidz Alquran Terhadap Peserta Didik di Sekolah Dasar Islam Khaira Ummah Kota Padang

\begin{tabular}{lll}
\hline \multicolumn{1}{c}{ Tema } & \multicolumn{1}{c}{ Informan } & \multicolumn{1}{c}{ Petikan Wawancara } \\
\hline Proses & Sahardi, & "...untuk menghafal Alquran menggunakan \\
Pembelajaran & S.IQ,S.Pd.I & $\begin{array}{l}\text { metode wahdah dan metode jama'. siswa } \\
\text { menghafal Alquran sebanyak tiga baris setiap }\end{array}$ \\
Tahfidz & & satu kali pertemuan dengan mengguankan \\
Alquran & metode wahdah dan menggunakan metode jama' \\
Terhadap & untuk mengulang hafalan dengan pendidik agar \\
Peserta Didik & bacaan sesuai dengan tajwid. Langkah dalam \\
di Sekolah & memilih metode tersebut adalah dengan melihat \\
Dasar Islam & pola belajar siswa dikelas, menyesuaikan kondisi \\
Khaira & semangat dan keseriusan siswa dalam belajar \\
Ummah Kota & dengan menerapkan metode tersebut." \\
Padang &
\end{tabular}


“....kami memilih metode tersebut, metode seperti wahdah dan jama' merupakan cara yang kami lakukan untuk proses mengfahal Alquran siswa. Sampai saat ini alhamdulillah metode ini sangat ampuh tanpa mengurangi aktivitas siswa dalam belajar bahkan metode ini lebih cepat ditangkap oleh siswa".

Berdasarkan hasil wawancara yang telah penulis jalankan kepada dua orang informan, secara keseluruhan hasil penelitian ini terdapat strategi pendidik yaitu dengan memilih metode untuk menghafal Alquran. Setelah dianalisis terdapat langkahlangkah yang dilakukan pendidik untuk memilih metode menghafal Alquran. Dari beberapa hasil wawancara dan observasi yang peneliti lakukan, bahwa strategi yang digunakan pendidik untuk meningkatkan hafalan Alquran siswa dengan melihat kondisi, pola belajar siswa di dalam kelas dan dengan menggunakan dua metode yaitu: Metode wahdah yaitu menghafal satu persatu ayat yang akan dihafal. Untukmencapai hafalan awal, setiap ayat hendaknya dibaca sebanyak sepuluh kali atau lebih hingga proses ini mampu membentuk pola dalam bayangan, untuk kemudian membentuk gerak reflek dari lisan. Metode selanjutnya jama' yaitu membaca ayat-ayat yang telah dihafal secara bersama- sama, dipimpin oleh seorang pendidik. Pendidik membimbingnya dengan mengulang kembali ayat-ayat tersebut dan siswa mengikutinya.

\section{Faktor Penghambat dan Faktor Pendukung}

Pada penerapan proses pembelajaran tahfidz di SD Islam Khaira Ummah Padang, terdapat hambatan saat proses menghafal Alquran dan juga terdapat faktor pendukung proses pembelajaran alquran. Berikut peneliti sajikan kutipan hasil wawancara dengan pak Sahardi, S.IQ, S.Pd. I dan pak Rino Ali, S.Pd.I yang menjabat sebagai guru tahfidz di Sekolah Dasar Islam Khaira Ummah Kota Padang. Proses wawancara ini dilakukan pada hari Senin 23 agutus dan Senin 30 Agustus 2021 di ruangan kelas Sekolah Dasar Khaira Ummah Padang.

Tabel 2. Petikan Wawancara Tentang Faktor Penghambat dan Pendukung

Tahfidz Alquran

\begin{tabular}{lll}
\hline \multicolumn{1}{c}{ Tema } & \multicolumn{1}{c}{ Informan } & \multicolumn{1}{c}{ Petikan Wawancara } \\
\hline Proses & Sahardi, & "...faktor yang menjadi penghambat siswa saat \\
Pembelajaran & S.IQ,S.Pd.I & menghafal Alquran,ketika saat proses menghafal \\
Tahfidz & & Alquran terdapat siswa yang bermain dengan \\
Alquran & temannya dan masih ada siswa tidak menguasai \\
Terhadap & hukum tajwid jadi harus ditahsin agar bacaan \\
Peserta Didik & Alquran siswa benar setelah itu baru boleh \\
di Sekolah & menghafal. Faktor pendukung siswa untuk \\
Dasar Islam & menghafal Alquran yaitumotivasi dan hadiah \\
Khaira & yang berikan pendidik yang membuat siswa \\
Ummah Kota & semangat untuk menghafal Alquran”. \\
Padang & \\
\hline
\end{tabular}


Rino Ali, S.Pd.I “...saat menghafal Alquran masih ada siswa yang tidak lancar membaca Alquran jadi harus ditahsin agar bacaan Alquran peserta didik benar setelah itu baru bolehmenghafal. Ketika proses menghafal Alquran terdapat siswa yang bermain dengan temannya.Kalau faktor pendukung siswa saat menghafal Alquran pendidik memberikan motivasi tentang manfaat menghafal Alquran untuk siswa, pendidik juga memberikan hadiah kepada siswa"

Pada penerapan proses pembelajaran tahfidz di SD Islam Khaira Ummah Padang, terdapat hambatan saat proses menghafal Alquran. Hasil wawancara mendapati dua hambatan yaitu siswa yang bermain-main dan siswa kurang menguasai hukum tajwid dalam alquran. Ditemukan juga faktor pendukung siswa untuk menghafal Alquran yaitu motivasi dan hadiah yang diberikan oleh pendidik. Wawancara dilakukan kepada pendidik dan siswa. Hasil wawancara bersama Informan pendidik pertama terkait hasil dari proses strategi pembelajaran yaitu faktor penghambat siswa dalam menghafal Alquran dan faktor pendukung siswa dalam menghafal Alquran.

Wawancara selanjutnnya kepada 5 orang peserta didik Lutfy Luqmanul Hakim, Lutfy Luqmanul Hakim, Arthifa Sukma Qalbi, Carissa Brilian Bartian dan Anin Bhianadira pada tanggal 8 dan 9 September pada hari rabu dan kamis, hasil wawancara yang peneliti dapatkan tentang faktor penghambat proses pembelajaran tahfidz yaitu peserta didik yang bermain saat proses menghafal Alquran sehingga menggangu konsentrasi temannya saat menghafal Alquran dan ada peserta didik yang tidak bisa membaca sesuai tajwid. Faktor pendukung peserta didik dalam menghafal Alquran yaitu motivasi dari guru tahfidz tentang keutamaan menghafal Alquran dan pemberian hadiah berupa nilai yang tinggi kepada peserta didik

\section{Solusi Guru Tahfidz dalam Mengatasi Hambatan Menghafal Alquran}

Pada aspek strategi guru tahfidz untuk meningkatkan kemampuan menghafal Alquran siswa kelas VI SD Islam Khaira Ummah Padang, hasil wawancara langsungbersama beberapa informan yaitu dua orang pendidik dan lima orang siswa mendapati hasil bahwa dalam solusi untuk mengatasi hambatan siswa dalam menghafal Alquran. Adapun Hambatan dalam menghafal Alquran adalah ketika menghafal Alquran ada siswa yang bermain sehingga menggangu temanya dan siswa yang belum lancar membaca Alquran. Namun demikian para pendidik memberikan dua solusi atas permasalahan tersebut yaitu pertama, pendidik menegur siswa yang bermain jika masih di ulangi maka diberi hukuman; kedua, siswa yang belum lancar membaca Alquran maka pendidik melakukan tahsin Alquran dengan siswa yang belum lancer membaca Alquran. Berikut peneliti sajikan kutipan hasil wawancara dengan 
pak Sahardi, S.IQ, S.Pd. I dan pak Rino Ali, S.Pd.I yang menjabat sebagai guru tahfidz di Sekolah Dasar Islam Khaira Ummah Kota Padang. Proses wawancara ini dilakukan pada hari Senin 23 agutus dan Senin 30 Agustus 2021 di ruangan kelas Sekolah Dasar Khaira Ummah Padang.

Tabel 2. Petikan Wawancara Tentang Solusi Guru Tahfidz dalam Mengatasi

Hambatan Menghafal Alquran

\begin{tabular}{|c|c|c|}
\hline Tema & Informan & Petikan Wawancara \\
\hline \multirow[t]{2}{*}{$\begin{array}{l}\text { Proses } \\
\text { Pembelajaran } \\
\text { Tahfidz } \\
\text { Alquran } \\
\text { Terhadap } \\
\text { Peserta Didik } \\
\text { di Sekolah } \\
\text { Dasar Islam } \\
\text { Khaira } \\
\text { Ummah Kota } \\
\text { Padang }\end{array}$} & $\begin{array}{l}\text { Sahardi, } \\
\text { S.IQ,S.Pd.I }\end{array}$ & $\begin{array}{l}\text { “...untuk menghafal bagi siswa itu tergantung } \\
\text { siswanya masing-masing sebab menghafal butuh } \\
\text { usaha dan kesabaran, namun pada pembelajaran } \\
\text { tahfidz masih ada siswa yang tidak serius } \\
\text { menghafal malahan bermain dengan temannya, } \\
\text { pendidik harus sabar dalam menyikapinya. siswa } \\
\text { harus ditegur ketika bermain sama temannya } \\
\text { karna bisa menggangu siswa lain, jika masih } \\
\text { diulangi maka pendidik akan memberikan } \\
\text { hukuman agar siswa tidak menggagu temannya. } \\
\text { Ada juga siswa yang belum lancar membaca } \\
\text { Alquran makan pendidik akan melakukan tahsin } \\
\text { sampai siswa membaca Alquran dengan benar, } \\
\text { barulah dibolehkan lagi menghafal Alquran. }\end{array}$ \\
\hline & Rino Ali, S.Pd.I & $\begin{array}{l}\text { "....pada saat mata pelajaran tahfidz ada siswa } \\
\text { yang tidak lancar membaca Alquran maka } \\
\text { pendidik harus melakukan tahsin kepada siswa } \\
\text { tersebut sampai bisa membaca Alquran dengan } \\
\text { dengan dengan cara mengikuti pendidik ketika } \\
\text { membaca Alquran perbaris setelah lancar makan } \\
\text { diperbolehkan siswa untuk melanjutkan proses } \\
\text { menghafal Alquran. siswa ada yang terganggu } \\
\text { saat ada temannya yang bermain saat proses } \\
\text { menghafal Alquran maka siswa harus } \\
\text { memberikan teguran agar siswayang bermain itu } \\
\text { agar melanjutkan hafalannya, jika masih diulangi } \\
\text { maka pendidik akan memberikan hukuman agar } \\
\text { siswa tidak menggagu temannya." }\end{array}$ \\
\hline
\end{tabular}

Wawancara selanjutnnya kepada 5 orang peserta didik Lutfy Luqmanul Hakim, Lutfy Luqmanul Hakim, Arthifa Sukma Qalbi, Carissa Brilian Bartian dan Anin Bhianadira pada tanggal 8 dan 9 September pada hari rabu dan kamis, hasil wawancara yang peneliti dapatkan tentang solusi guru tahfid dalam mengatasi hambatan menghafal Alquran yaitu guru tahfidz memberikan teguran kepada peserta didik yang bermain, jika masih diulangi maka peserta didik memberikan hukuman kepada peserta agar tidak mengulangi kesalahannya lagi. Peserta didik yang tidak bisa membaca 
Anwar Fuadi Jalil dan Alfurqan : Proses Pembelajaran Tahfidz Alquran ....

Alquran dengan lancar guru tahfidz akan mengajarinya sampai bisa membaca Alquran dengan lancar setelah itu dibolehkan menghafal Alquran.

Dari hasil penelitian di atas terdapat poin-poin penting yang perlu dibahas mengenai strategi pendidik tahfidz dalam meningkatkan kemampuan menghafal Alquran siswa. Menurut Firmansyah (2015) strategi pembelajaran adalah kegiatan pembelajaran yang harus dikerjakan guru dan siswa agar tujuan pembelajaran dapat dicapai secara efektik dan efisien. Pembahasan sekarang tentang strategi untuk meningkatkan kemampuan menghafal Alquran siswa.

Cara kemampuan siswa dalam menghafal dan memahami hafalannya berbeda-beda ada yang mudah menghafal dan ada yang kesulitan dalam menghafal, maka dari itu diperlukan nya strategi pendidik dalam mempermudah siswa untuk menghafal. Strategi yang pendidik gunakan dalam meningkatkan kemampuan menghafal Alquran siswa dengan menggunakan dua metode yaitu menggunakan:

a. Metode wahdah, siswa membawa Alquran sendiri-sendiri dari rumah masingmasing sebelum menyetorkan hafalan membiasakan menghafal satu persatu ayat siswa di ajurkan membaca sebanyak sepuluh kali atau lebih yang akan mereka hafal sehingga siswa terbiasa dan setelah mereka hafal bisa melanjutkan ayat yang lain membiasakan siswa mempunyai target yang akan di capai setiap pertemuan.

b. Metode jama' yaitu siswa dapat membaca secara bersama-sama dengan pendidik. Pendidik sebagai instruktur membacakan terlebih dahulu ayat-ayat secara sedikit demi sedikit siswa memperhatikan surat yang sedang di baca kemudian siswa mengikutinya secara bersamaan.

Metode yang pendidik berikan dapat di terapkan siswa dalam pembelajaran yang menurut nya lebih memudahkan mereka dalam menghafal walau masih ada siswa yang lebih memilih untuk menyetorkan hafalan secara individu dengan pendidik. Setiap proses hafalan pendidik membiasakan siswa untuk mencapai target yang harus di capai setiap pertemuan. Strategi pendidik sangat di harapkan untuk meningkatkan kemampuan siswa dalam menghafal Alquran, menjadikan siswa lebih kreatif, mandiri serta mempunyai rasa tanggung jawab yang besar.

Selain siswa menghafal disekolah mereka juga diberi tugas untuk menghafal dirumah dengan malanjutkan hafalan berikutnya. Ketika menghafal dirumah siswa ada belajar sendiri karna faktor orang tua yang sudah lelah saat bekerja dan juga siswa dibantu oleh orang tua untuk menyimak apa yang siswa hafal supaya hafalannya benar dan tidak terjadi kesalahan dalam membaca, selain itu pendidikan orang tua di dalam keluarga sangat berperan penting terhadap keberhasilan siswa dalam belajar.

Siswa mempunyai cara sendiri dalam menghafal yang mana menurut mereka yang nyaman di gunakan, dalam metode yang pendidik pakai ada siswa yang mengikuti metode yang pendidik gunakan menurut mereka itu lebih mudah. Menghafal disarankan kepada siswaan pada waktu pagi hari karena ketika masih pagi otak dapat bekerja dengan baik, kemudian dalam menghafal Alquran pendidik lebih memilih dikelas agar situasi kelas lebih terkendali. Setiap sekali pertemuan siswa diharapkan bisa menghafal sebanyak tiga baris Alquran, karena jika per ayat tidak bisa karna ada ayat yang panjang dan juga ada ayat yang pendek.

Bagi siswa yang tidak hafal dalam waktu yang ditentukan maka besok hafalanya akan bertambah, siswa harus berusaha mengejar hafalan yang tertinggal. Kesulitan 
dalam menghafal siswa karena tidak lancar membaca Alquran jadi pendidik melakukan tahsin kepada siswa sampai bisa membaca Alquran dengan benar, setelah bisa membaca Alquran dengan benar maka siswa dibolehkan melanjutkan menghafal Alquran.

Dalam hal ini pendidik harus membantu siswa untuk menghafal agar sesuai dengan target yang ingin ditempuh setiap harinya. Pendidik harus selalu memberikan motivasi kepada siswa agar selalu bersemangat dalam menghafal Alquran dan pendidik juga memberikan hadiah berupa nilai yang tinggi bagi siswa yang memperoleh hafalan yang terbaik. Motivasi baik bagi siswa supaya bersemangat dalam belajar dan pantang untuk menyerah agar mereka tidak tertinggal dengan teman-temannya yang lain agar mendapatkan prestasi yang memuaskan.

Menurut Sulastri (2017) Hadiah (reward) adalah alat untuk mendidik anak-anak supaya anak senang karena perbuatan atau pekerjaannya mendapat penghargaan. Sedangkan hukuman (punishment) merupakan bentuk tindakan seseorang dalam memberikan penderitaan dengan sengaja kepada siswa yang menjadi asuhan pendidik, dengan harapan agar penderitaan itu betul-betul dirasakan siswa, untuk menuju ke arah perbaikan (zamzami, 2018). Jadi dapat disimpulkan bahwa pengaruh motivasi, hadiah dan hukuman untuk sebuah pencapaian hafalan merupakan hal yang bagus dikarenakan maksud motivasi, hadiah dan hukuman untuk mendorong siswa lebih bersemangat untuk belajar.

Dari temuan penelitian diatas dalam penerapan strategi pendidik juga menemukan hambatan saat proses menghafal Alquran. Hambatan yang sering ditemui siswa ada yang bermain-main saat jam pelajaran tahfidz sehingga mengganggu siswa lain yang akan menghafal, kosentrasi sangat diperlukan saat menghafal agar hafalannya mudah untuk diingat akan tetapi saat kosentrasi nya terganggu itulah yang menyebabkan siswa sulit untuk mengingat apa yang sudah di hafal. Pada saat menghafal Alquran ada siswa yang tidak lancar membaca Alquran sehingga harus melakukan tahsin dulu dengan pendidik sampai siswa bisa membaca Alquran dengan benar. Kerjasama antara pendidik dan siswa sangat diharapakan akan keberhasilan dalam belajar bisa mengatur waktu sehingga siswa merasa nyaman.

Selain terdapat faktor penghambat dalam proses menghafal terdapat juga faktor pendukung dalam meningkatkan hafalan siswa yaitu dengan memberikan motivasi terhadap siswa sebelum memulai aktivitas belajar mengajar guna mendapatkan hafalan yang baik, pertemuan antara pendidik dan murid yang intensif di maksudkan dimana agar adanya interaksi antara pendidik dan siswa saat proses pembelajaran. Selain dari faktor hambatan peneliti juga mencari tahu tentang solusi yang diberikan pendidik untuk mengatasi hambatan dalam proses hafalan diantaranya dalam kejadian siswa yang masih bermain-main saat jam belajar hafalan, pendidik menegur siswa tersebut agar tidak bermain lagi, apabila masih mengulanginya maka akan diberi hukuman.

Hukuman sangat diperlukan dalam mendidik anak yang tidak bisa mengikuti aturan yang pendidik berikan. Akan tetapi hukuman yang diberikan tidak terlalu berakibat fatal bagi siswa hukuman tersebut diberikan jika siswa tidak dapat di nasehati lagi. Hukuman bertujuan untuk memberikan efek jera kepada siswa agar tidak mengulangi lagi kesalahannya. Dalam penelitian yang dilakukan Wulandari dan Hidayat (2014), dengan adanya pemberian hukuman kegiatan belajar mengajar dapat menumbuhkan 
motivasi dan respon dari siswa agar menjadi lebih baik dalam melakukan sesuatu. Menurut Ellyana (2019) hukuman adalah tindakan yang dijatuhkan kepada anak secara sadar dan sengaja sehingga menimbulkan nestapa bagi anak dan akan menjadi sadar atas perbuatan dan berjanji di dalam hatinya untuk tidak mengulanginya.

Kemudian siswa yang sulit dalam menghafal Alquran karena belum membaca Alquran dengan benar maka pendidik akan membantu siswa dengan melakukan tahsin Alquran sampai siswa bisa membaca Alquran dengan benar, setelah itu barulah siswa boleh melanjutkan hafalan Alquran. Tujuan pendidik melakukan tahsin agar siswa bisa menghafal Alquran dengan benar, tapi jika bacaannya salah siswa tetap menghafal Alquran maka akan susah mengubah bacaan siswa yangs salah tersebut.

Menurut Hikmah (2020) tahsin Alquran adalah upaya memperbaiki dan membaguskan bacaan dalam Alquran. Agar lebih mudah memahami makna yang terkandung di dalamnya, kita harus berhati-hati dalam membacanya baik dari segi makharijul huruf, sifat-sifatnya, maupun ilmu tajwidnya. Sedangkan menurut Nurkarima (2015) membaca Alquran yang tidak menuruti ilmu tajwid hukumnya dosa, kesalahan ucapan dalam membaca Alquran dapat menyebabkan salah pengertian. Huruf yang dibaca panjang tetapi diucapkan pendek atau sebaliknya huruf yang dibaca pendek tetapi diucapkan panjang akan menyebabkan terjadinya perubahan makna. Akibatnya kalau terjadi salah pengertian dalam memahami Alquran tentu akan menyebabkan terjadinya kesalahan amal keagaaman. Oleh karena itu guru harus mengajari siswa tahsin Alquran sampai bisa membaca Alquran dengan benar agar tidak terjadi kesalahan dalam membaca Alquran karena bisa merubah arti dari Alquran

\section{Simpulan}

Berdasarkan hasil penelitian sebagaimana telah penulis ungkapkan pada Bab IV, maka dapat diambil kesimpulan sebagai berikut strategi yang dipakai oleh pendidik yang telah diterapkan oleh peserta didik mengggunakan dua metode yaitu: metode wahdah dan metode jama. Metode wahdah dan metode jama' memiliki keunggulan masing-masing, siswa yang pintar cepat menghafal Alquran dan bisa lebih banyak lagi hafalannya, sementara siswa yang lain ketinggalan jika hanya menggunakan metode wahdah. Ketika menggunakan metode jama, semuanya bisa sama-sama hafal, jadi sebaiknya dua metode ini wahdah dan jama' dipakai untuk proses menghafal Alquran guru tahfidz bisa meningkatkan hafalan siswa karena dengan metode tersebut siswa bisa menghafal Alquran dengan semangat sehingga banyak ayat-ayat Alquran yang dihafal.

\section{Referensi}

A'la al Maududi, A., Mujahidin, E., \& Hafidhuddin, D. (2014). Metode Tahfizh Alquran bagi Pelajar dan Mahasiswa. Ta'dibuna, 3(1), 1-15.

Akmal, R. (2021). Learning Tahfidz Quran Method in North Lintau Buo Subdistrict Flat Land District. Ruhama: Islamic Education Journal, 4(1).

Al-Hafizh, Ahsin W. 2003. Bimbingan Praktis Menghafal Alquran. Jakarta: PT Bumi Aksara.

Anggito, A., \& Setiawan, J. (2018). Metodologi penelitian kualitatif. CV Jejak (Jejak Publisher).

Baik. ELEMENTARY: Islamic Teacher Journal, 6(2), 301-313. 
Darimi, I. (2015). Peningkatan Kompetensi Pedagogik Guru PAI dalam Pembelajaran. Jurnal MUDARRISUNA: Media Kajian Pendidikan Agama Islam, 5(2), 309-324.

Departemen Pendidikan Nasional. (2003). Undang-Undang RI No 20 Tahun 2003. Jakarta: Depdiknas.

Departemen Pendidikan Nasional. (2005). Undang-Undang RI No 14 Tahun 2005. Jakarta: Depdiknas.

Edi, F. R. S. (2016). teori wawancara Psikodignostik. Penerbit LeutikaPrio.

Efendi, A. (2008). Peran Strategis Lembaga Pendidikan Berbasis Islam di Indonesia. El Tarbawi, 1(1), 1-12.

Ellyana, E. (2019). Manfaat Hukuman Dalam Pengajaran Pendidikan Agama Islam Di Sekolah. At-Ta'lim: Media Informasi Pendidikan Islam, 12(2), 313-328.

Fachrudin, Y. (2017). Pembinaan Tahfizh Al-Quran di Pesantren Tahfizh Daarul Alquran Tangerang. Kordinat: Jurnal Komunikasi antar Perguruan Tinggi Agama Islam, 16(2), 325-348.

Fanani, I. (2016). Problematika menghafal al Qur'an (Studi komparasi di pondok pesantren Tahfidzul Qur'an al Hasan Patihan Wetan dan pondok pesantren Nurul Qur'an Pakunden Ponorogo) (Doctoral dissertation, IAIN Ponorogo).

Fimansyah, D. (2015). Pengaruh Strategi pembelajaran dan minat belajar terhadap hasil belajar matematika. Judika (Jurnal Pendidikan UNSIKA), 3(1).

Gade, F. (2014). Implementasi Metode Takrar Dalam Pembelajaran Menghafal Alquran. jurnal ilmiah didaktika: Media Ilmiah Pendidikan dan Pengajaran, 14(2). Hashim, A. (2015). Hubungan Strategi Gaya Belajar Tahfiz dengan Kinerja Siswa dalam Menghafal Alquran (Hifz). Jurnal Mediterania Ilmu Sosial, 6 (2 S5), 85.

Hidayah, N. (2016). Strategi Pembelajaran Tahfidz Alquran di Lembaga Pendidikan. Ta'allum: Jurnal Pendidikan Islam, 4 (1), 63-81.

Hidayat, N. (2018). Kolaborasi Guru Kelas dan Tahfidz Dalam Meningkatkan Konsep Diri Peserta Didik Kelas Atas Penghafal Alquran Di SDIT Baik. ELEMENTARY: Islamic Teacher Journal, 6(2), 301-313.

Hikmah, S. A. N. (2020). Pembelajaran Tahsin Alquran Pada Santri Kelas 1 Madrasah Diniyah Pondok Pesantren Alquran Al-Amin Pabuwaran, Purwokerto Utara (Doctoral dissertation, IAIN).

Ishak, S. H. (2017). Penerapan Model Pembelajaran Kooperatif Make A Match Dalam Menghafal Surah-Surah Pendek Di Madrasah Ibtidaiyah Al-Muhajirin Bitung (Doctoral Dissertation, IAIN Manado).

Latifah, E. (2016). Kemampuan menghafal Alquran siswa kelas VIII SMP Takhassus Plus Al-Mardliyah (studi deskriptif pada siswa kelas VIII SMP Takhassus Plus AlMardliyah Kaliwungu Selatan Kendal) (Doctoral dissertation, UIN Walisongo).

Mahmud, 2010, Psikologi Pendidikan, Bandung: Pustaka Setia

Marfu'ah, J., \& Dewi, R. (2007). Perbedaan Kreativitas Pada Siswa SD (SD) Dan SD Islam Terpadu (SDIT). 
Anwar Fuadi Jalil dan Alfurqan : Proses Pembelajaran Tahfidz Alquran....

Mashud, I. (2019). Meningkatkan Kemampuan dalam Setoran Hafalan Alquran Melalui Metode Talaqqi Pada Siswa Kelas VI B SD Islam Yakmi Tahun 2018. Naturalistic: Jurnal Kajian Penelitian Pendidikan dan Pembelajaran, 3(2), 347-358.

Mundiri, A., \& Zahra, I. (2017). Implementasi Metode STIFIn dalam Meningkatkan Kemampuan Menghafal Alquran di Rumah Alquran STIFIn Paiton.

Nasution, W. N. (2017). Strategi pembelajaran. Medan : Perdana Publishing

Novianti, R. (2012). Teknik Observasi bagi pendidikan anak usia dini. Jurnal Educhild:

Pendidikan dan Sosial, 1(1), 22-29.

Nurkarima, R. (2015). Analisis Pengelolaan Pembelajaran Tahsin dan Tahfidz AlQur'an dengan Metode Talaqqi Kelas VIII di SMPIT Qordova Rancaekek.

Probolinggo. Jurnal Pendidikan Agama Islam Uournal of Islamic Education Studies), 5(2), 201-223.

Qoyyum, Muhammad bin Abdul, Taqiyul Muhammad Islam, 2009, Keajaiban Hafalan, Bimbingan Bagi yang Ingin Menghafal Alquran, Yogyakarta: Pustaka Al-Haura

Rizalludin, A. (2019). Implementasi Metode Talaqqi Dalam Pembelajaran Tahsin Dan Tahfiz Alquran. Khazanah Pendidikan Islam, 1(1), 33-37.

Salamah, U. (2018). Pengajaran Menggunakan Metode Kaisa dalam Menghafal Al Quran pada Anak. TaLimuna: Jurnal Pendidikan Islam, 7(2), 124-128.

Sanusi, HP (2013). Peran Guru PAI Dalam pengembangan Nuansa religius di sekolah. Jurnal Pendidikan Agama Islam-Ta'lim , 11 (2), 143-153.

Semiawan, C. R. (2010). Metode penelitian kualitatif. Grasindo.

Siswanto, H. (2018). Hubungan Kemampuan Menghafal Al Alquran Dan Motivasi Belajar Dengan Hasil Belajar PAI Siswa Madrasah Aliyah Al Fathimiyah Banjarwati Paciran Lamongan. Darajat: Jurnal Pendidikan Agama Islam, 1(1), 7894.

Sugiyono. (2008). Metode Penelitian Kualitatif, Kuantitatif dan R\&D. Bandung: Alfabeta.

Sulastri, D. (2017). Penerapan Reward dan Punishment Untuk Meningkatkan Prestasi Belajar Siswa Dalam Pembelajaran IPA Sub Pokok Bahasan Energi Kelas Ii Mi Al Ikhlas Karangpucung Kecamatan Purwokerto Selatan Tahun Pelajaran 2016/2017 (Doctoral dissertation, IAIN).

Umar Husein, (2001). Strategic Management in Action. Jakarta : Gramedia

Wulandari, I.S., \& Hidayat, T. (2014). Pengaruh Pemberian Reward And Hukuman Terhadap Motivasi Belajar Siswa Dalam Pembelajaran Passing Bawah. Jurnal Pendidikan Olahraga dan Kesehatan, Vol. 2, No. 3, Hal. 599 - 604.

Zamzami, M. R. (2018). Penerapan Reward and Punishment dalam Teori Belajar Behaviorisme. TaLimuna: Jurnal Pendidikan Islam, 4(1), 1-20.Al-Hafizh, Ahsin W. 2003. Bimbingan Praktis Menghafal Alquran. Jakarta: PT Bumi Aksara.

Zuhairini dan Abdul Ghofir. 2004. Metodologi Pembelajaran Pendidikan Agama Islam. Malang: UM Press. 